\title{
Pengaruh Pemberian Vitamin C terhadap Kadar Leukotrien Urin pada Pasien Asma Anak
}

\author{
Cece Alfalah, * Gustina Lubis, * Finny F Yani, * Nur I Lipoeto ** \\ * Bagian Ilmu Kesehatan Anak, ** Bagian Ilmu Gizi Fakultas Kedokteran Universitas Andalas/RS. Dr. \\ M. Djamil, Padang
}

\begin{abstract}
Latar belakang. Pada asma anak terdapat peningkatan kadar leukotrien darah dengan hasil metabolit akhir berupa leukotrien $\mathrm{E}_{4}\left(\mathrm{LTE}_{4}\right)$. Vitamin $\mathrm{C}$ dapat menghambat lipoksigenase sehingga menurunkan kadar $\mathrm{LTE}_{4}$ urin sejalan dengan perbaikan klinis asma.

Tujuan. Mengetahui pengaruh pemberian vitamin $\mathrm{C}$ terhadap perbaikan klinis asma anak, ditandai dengan penurunan kadar $\mathrm{LTE}_{4}$ urin dan peningkatan nilai C-ACT.

Metode. Penelitian intervensi (pre and post group design) pemberian vitamin C $200 \mathrm{mg} / \mathrm{hari}$ setelah makan selama 6 minggu, dilakukan pada pasien asma anak dari bulan September sampai dengan Oktober 2013. Kadar $\mathrm{LTE}_{4}$ urin normal $10-60 \mathrm{pg} / \mathrm{ml}$ dan nilai C-ACT terkontrol $\geq 20$. Perbedaan dua data numerik tidak berdistribusi normal diuji dengan uji Wilcoxon-Rank $(\mathrm{p}<0,05)$. Korelasi antara dua data numerik tidak berdistribusi normal diuji dengan korelasi Spearman

Hasil. Pemberian vitamin C tidak menurunkan kadar $\mathrm{LTE}_{4}$ urin (60,5\%), tetapi terdapat kecenderungan peningkatan nilai C-ACT (50\%), p >0,05. Terdapat korelasi antara kadar $\mathrm{LTE}_{4}$ urin dan nilai C-ACT sebelum dan setelah pemberian vitamin $C(r=-0,327$ dan $-0,359 ; p<0,05)$. Terdapat penurunan kejadian serangan asma setelah pemberian vitamin $\mathrm{C}, \mathrm{p}<0,05$.

Kesimpulan. Pemberian vitamin C dapat memperbaiki klinis asma, meskipun kadar $\mathrm{LTE}_{4}$ urin dan nilai C-ACT tidak mempunyai korelasi sebelum dan setelah pemberian vitamin C. Sari Pediatri 2015;16(6):416-20.
\end{abstract}

Kata kunci: asma, vitamin $\mathrm{C}, \mathrm{LTE}_{4}$ urin

A

sma merupakan penyakit inflamasi kronis pada saluran napas. ${ }^{1}$ Perkiraan prevalensi total asma diperkirakan $7,2 \%$ di seluruh dunia, meningkat tajam akibat polusi udara dalam rumah seperti asap rokok dan luar rumah seperti

\footnotetext{
Alamat korespondensi:

Dr. Cece Alfalah. Bagian Ilmu Kesehatan Anak FK. Universitas Andalas/ RS. Dr. M. Djamil Padang. Jln. Perintis Kemerdekaan Padang. E-mail: cealfalah75@gmail.com.
}

asap knalpot kendaraan bermotor, ditambah lagi gaya hidup termasuk kebiasaan makan yang menurunkan asupan antioksidan seperti vitamin C. ${ }^{2}$ Sekitar 9\%$11 \%$ anak di bawah usia 18 tahun $(9,5 \%)$ menderita asma, $11,3 \%$ adalah anak laki-laki dan $7,7 \%$ anak perempuan. ${ }^{3}$

Serangan asma bervariasi mulai dari ringan sampai berat dan dapat mengancam kehidupan sehingga diperlukan peningkatan kontrol asma. ${ }^{4}$ Asthma Control Test (ACT) merupakan prediktor yang ditetapkan 
dalam pedoman Global Initiative for Asthma (GINA) untuk mengontrol asma dan menggambarkan efektifitas klinis setelah intervensi terapi. Untuk anak usia 4-11 tahun digunakan Childhood Asthma Control Test (C-ACT). ${ }^{5,6}$ Kontrol asma berdasarkan skor C-ACT' dibagi menjadi 3 klasifikasi, yaitu $\geq 20$ baik, 13-19 tidak baik, dan $\leq 12$ sangat buruk. ${ }^{7}$

Leukotrien adalah suatu bronkokonstriktor yang poten, selain dapat meningkatkan sekresi mukus dan memfasilitasi perembesan plasma yang menyebabkan edema saluran napas, sehingga dianggap menjalankan peran penting dalam patogenesis asma. ${ }^{8}$ Leukotrien sebagai mediator lipid dibentuk melalui tahapan enzimatik multipel. Fosfolipid merupakan senyawa yang banyak tersedia pada membran sel dan dapat dimetabolisme secara enzimatik oleh fosfolipase $A_{2}$. Asam arakidonat yang dilepaskan oleh enzim tersebut kemudian dimetabolisasi melalui berbagai jalur. Enzim 5-LO (5-lipoksigenase) merupakan satu-satunya jalur yang menghasilkan leukotrien. Aktivasi 5-LO pada sel diperkirakan membutuhkan aktivasi keseluruhan sel dengan mobilisasi cadangan kalsium dan ketersediaan asam arakidonat sebagai substrat.?

Ikatan arakidonat dengan protein pengaktif 5-LO (five-lipoxygenase activating protein, FLAP) diperkirakan berperan dalam presentasi arakidonat ke 5-LO. Aktivasi 5-LO, baik pada sitoplasma maupun pada membran sel, menghasilkan senyawa antara yang tidak stabil yaitu $\mathrm{LTA}_{4}$ yang dapat dimetabolisasi lebih lanjut tergantung jenis sel, menjadi $\mathrm{LTB}_{4}$ atau sisteinilLTs (cystLTs), $\mathrm{LTC}_{4}, \mathrm{LTD}_{4}$ dan $\mathrm{LTE}_{4}$. Enzim $\mathrm{LTC}_{4}$ sintase terdapat di dalam sel mast, eosinofil, basofil, dan makrofag yang memetabolisir LTA $_{4}$ menjadi $\mathrm{LTC}_{4}{ }^{10}$ Enzim $\mathrm{LTC}_{4}$ kemudian secara cepat diubah menjadi $\mathrm{LTD}_{4}$ dan $\mathrm{LTE}_{4}$ dengan bantuan enzim gamma glutamil transpeptidase dan suatu dipeptidase. ${ }^{9}$ Enzim $\mathrm{LTC}_{4}$ merupakan cysLTs intraselular dan dapat dideteksi di dalam sel, sedangkan $\mathrm{LTD}_{4}$ dibentuk eksraselular dari $\mathrm{LTC}_{4}$ setelah dikeluarkan ke ruang ekstraselular. ${ }^{10}$ Enzim LTC 4 dan $\mathrm{LTD}_{4}$ memiliki waktu paruh yang sangat pendek sementara $\mathrm{LTE}_{4}$ merupakan bentuk yang paling stabil dari ketiganya dan dengan waktu paruh terpanjang, tetapi memiliki afinitas reseptor terendah. ${ }^{9}$

Vitamin C merupakan vitamin yang larut di dalam air dan berperan dalam patogenesis asma. Penelitian invitro menemukan bahwa vitamin $C$ dapat menghambat enzim 5-LO sehingga menurunkan produksi $\mathrm{LTE}_{4}{ }^{11}$ Meskipun vitamin $\mathrm{C}$ dapat menurunkan produksi leukotrien dengan penghambatan lipoksigenase secara invitro, masih sedikit penelitian yang meneliti pengaruh vitamin $C$ terhadap kadar leukotrien secara invivo. Penelitian ini bertujuan untuk mengetahui pengaruh pemberian vitamin $\mathrm{C}$ terhadap perbaikan klinis asma pada anak.

\section{Metode}

Penelitian intervensi (pre and post group design) dilakukan di RS. Dr. M. Djamil dan di laboratorium Biomedik Fakultas Kedokteran Universitas Andalas FK UNAND) pada bulan September 2013 sampai dengan Oktober 2013. Populasi penelitian adalah semua pasien asma anak berusia 6-11 tahun yang berobat ke RS. Dr. M. Djamil Padang dan terdata dalam data internal subbag Respirologi IKA FK UNAND. Pengambilan sampel dilakukan secara konsekutif, yaitu semua populasi yang memenuhi kriteria inklusi (usia 6-11 tahun yang berobat jalan ke Poliklinik Anak dan atau pernah dirawat di Bangsal IKA RS. Dr. M. Djamil Padang serta bersedia menjadi responden) dan tidak terdapat kriteria eksklusi (pasien asma anak yang menggunakan controller: kortikosteroid, leukotrien antagonis/montelukast, zafirlukast, pranlukast; pindah ke luar Padang; dan menarik diri sebelum penelitian selesai) sampai mencapai batas besar sampel (40 orang). Variabel penelitian terdiri atas variabel bebas (vitamin C) dan variabel tergantung (kadar $\mathrm{LTE}_{4}$ urin dan nilai C-ACT). Kriteria nilai C-ACT sampel dikelompokkan menjadi tiga kriteria, yaitu $\geq 20$ baik, $13-19$ tidak baik, dan $\leq 12$ sangat buruk.

Penelitian dilakukan setelah lulus seleksi dari Komite Etik RS. Dr. M. Djamil Padang yang diterbitkan pada tanggal 27 Agustus 2012 dengan Nomor. PE. 34. 2012. Informed consent diminta kepada orang tua atau wali pasien asma anak. Intervensi berupa pemberian vitamin C dosis $200 \mathrm{mg} /$ hari setelah makan selama 6 minggu. Sebelum dan setelah intervensi dilakukan pengambilan sampel urin dan pengisian kuesioner C-ACT. Pengawasan pemberian vitamin C dilakukan oleh peneliti dan orang tua/wali. Pemeriksaan $\mathrm{LTE}_{4}$ urin menggunakan metode Enzymelinked immunosorbent assay (ELISA), konsentrasi $\mathrm{LTE}_{4}$ urin didasarkan kepada kurva standar yang didapatkan dari $\mathrm{LTE}_{4}$ standar. Prosedur pemeriksaan sesuai prosedur dari Cayman Chemical ACE EIA kit.

Semua data yang diperoleh dicatat di dalam 
lembaran khusus. Data diolah dan disajikan dalam bentuk tabel dan grafik. Perbedaan dua data numerik yang berdistribusi tidak normal diuji dengan uji Wilcoxon-Rank, nilai $\mathrm{p}<0,05$ dianggap bermakna. Korelasi antara dua data numerik yang tidak berdistribusi normal diuji dengan korelasi Spearman. Korelasi mutlak akan memberikan nilai $\mathrm{r}=1$, yang nyaris tidak pernah ada dalam fenomena biologis. Nilai $r$ ditafsirkan baik $(r>0,8)$, sedang $(r=0,6-0,79)$, lemah $(r=0,4-0,59)$, sangat lemah $(r<0,4) .{ }^{11}$

\section{Hasil}

Penelitian dilakukan pada 40 pasien asma anak, dua orang tidak dapat melanjutkan penelitian karena pindah ke luar kota Padang sehingga subjek yang ada 38 orang. Lebih separuh sampel berjenis kelamin perempuan (20/38), mempunyai riwayat alergi dalam keluarga (21/38), menderita asma episodik jarang (33/38), dan termasuk terkontrol baik berdasarkan nilai C-ACT $\geq 20$ (25/38). Rerata \pm SB sampel berdasarkan umur, berat badan, tinggi badan dan IMT masing-masing $106,05 \pm 22,27$ bulan ( $8,83 \pm 1,85$ tahun), $25,97 \pm 7,05$ $\mathrm{kg}, 129,18 \pm 10,92 \mathrm{~cm}$ dan $15,36 \pm 2,85 \mathrm{~kg} / \mathrm{m}^{2}$. Status gizi sampel penelitian 19/38 merupakan gizi kurang, $15 / 38$ gizi baik, $3 / 38$ obesitas dan 1/38 overweight. Karakteristik subjek tertera pada Tabel 1.

Tabel 2 menunjukkan pemberian vitamin $\mathrm{C}$ tidak menurunkan kadar $\mathrm{LTE}_{4}$ urin secara bermakna $(\mathrm{p}=0,172)$. Distribusi jumlah anak berdasarkan frekuensi kadar $\mathrm{LTE}_{4}$ urin setelah pemberian vitamin

Tabel 1. Karakteristik subjek

\begin{tabular}{|c|c|c|}
\hline Karakteristik & Rerata \pm SB & $\mathrm{n}$ \\
\hline \multicolumn{3}{|l|}{ Jenis kelamin } \\
\hline Laki-laki & & 18 \\
\hline Perempuan & & 20 \\
\hline Umur (bulan) & $106,05 \pm 22,27$ & \\
\hline Berat badan $(\mathrm{kg})$ & $25,97 \pm 7,05$ & \\
\hline Tinggi badan $(\mathrm{cm})$ & $129,18 \pm 10,92$ & \\
\hline IMT $\left(\mathrm{kg} / \mathrm{m}^{2}\right)$ & $15,36 \pm 2,85$ & \\
\hline \multicolumn{3}{|l|}{ Status gizi (\%) } \\
\hline Kurang & & 19 \\
\hline Baik & & 15 \\
\hline Overweight & & 1 \\
\hline Obesitas & & 3 \\
\hline \multicolumn{3}{|l|}{ Riwayat alergi dalam keluarga } \\
\hline Ada & & 21 \\
\hline Tidak ada & & 17 \\
\hline \multicolumn{3}{|l|}{ Asma episodik } \\
\hline Jarang & & 33 \\
\hline Sering & & 5 \\
\hline \multicolumn{3}{|l|}{$\begin{array}{l}\text { Kontrol asma berdasarkan nilai } \\
\text { C-ACT }\end{array}$} \\
\hline Terkontrol baik ( $\geq 20$ ) & & 25 \\
\hline Terkontrol tidak baik (13-19) & & 13 \\
\hline
\end{tabular}

Tabel 2. Kadar $\mathrm{LTE}_{4}$ urin sebelum dan setelah pemberian vitamin C

\begin{tabular}{lcccc}
\hline Sampel & $\begin{array}{r}\text { Rerata } \\
(\mathrm{pg} / \mathrm{ml})\end{array}$ & SB & Interval kepercayaan & $\mathrm{p}$ \\
\hline Sebelum perlakuan & 532,02 & 80,72 & $505,49-558,55$ & 0,172 \\
Setelah perlakuan & 547,57 & 76,75 & $522,34-572,79$ & \\
\hline
\end{tabular}

Tabel 3. Nilai C-ACT sebelum dan setelah pemberian vitamin C

\begin{tabular}{lcccc}
\hline Sampel & Rerata & SB & Interval kepercayaan & p \\
\hline Sebelum perlakuan & 20,13 & 2,04 & $19,46-20,80$ & 0,134 \\
Setelah perlakuan & 20,50 & 2,05 & $19,82-21,17$ & \\
\hline
\end{tabular}

Tabel 4. Distribusi jumlah anak berdasarkan nilai C-ACT setelah pemberian vitamin C

\begin{tabular}{lcc}
\hline Peningkatan nilai C-ACT & Frekuensi & Persentase \\
\hline Ada & 19 & 50,0 \\
Tidak ada & 19 & 50,0 \\
\hline Total & 38 & 100,0 \\
\hline
\end{tabular}


C, yaitu penurunan $\mathrm{LTE}_{4}$ urin $15 / 38$ dan tidak terdapat penurunan 23/38.

Tabel 4 menunjukkan pemberian vitamin $\mathrm{C}$ tidak meningkatkan nilai C-ACT secara bermakna $(\mathrm{p}=0,134)$, tetapi $50 \%$ subjek menunjukkan peningkatan nilai C-ACT. Terdapat perbedaan yang bermakna $(\mathrm{p}=0,035)$ jumlah kejadian serangan asma sebelum perlakuan pemberian vitamin C (19 anak) dengan setelah perlakuan (10 anak). Uji Spearman mendapatkan korelasi negatif dengan kekuatan korelasi yang sangat lemah antara kadar $\mathrm{LTE}_{4}$ urin dan nilai C-ACT sebelum pemberian vitamin $C(p=0,045)$, demikian juga antara kadar $\mathrm{LTE}_{4}$ urin dan nilai C-ACT setelah pemberian vitamin $C(p=0,027)$.

\section{Pembahasan}

Pemberian vitamin $\mathrm{C}$ tidak menurunkan kadar $\mathrm{LTE}_{4}$ urin secara bermakna. Hasil tersebut berbeda dengan laporan oleh Al-Blitagi dkk, ${ }^{14}$ di Mesir, yang mendapatkan penurunan cystLT yang bermakna setelah pemberian vitamin C. Severien $\mathrm{dkk},{ }^{13} \mathrm{di}$ Jerman, menggunakan kit EIA yang sama untuk pemeriksaan $\mathrm{LTE}_{4}$ urin, tetapi tidak dilakukan intervensi. Konsentrasi $\mathrm{LTE}_{4}$ urin pada anak asma dibandingkan dengan kontrol dan menunjukkan konsentrasi $\mathrm{LTE}_{4}$ lebih tinggi pada anak asma dibandingkan dengan kontrol (median 238,5 (126,5$375,7)$ SD 191,8 versus 189 (51-253,2) SD 131,7 pg. $\mathrm{mg}^{-1}$ kreatinin; $\mathrm{p}=0,021$ ).

Pemberian vitamin $\mathrm{C}$ tidak meningkatkan nilai C-ACT. Hasil tersebut berbeda dengan laporan Hemilia dkk ${ }^{14}$ di Mesir, yang mendapatkan bukti kuat bahwa pengaruh vitamin $\mathrm{C}$ pada anak asma adalah heterogen. Dampak pemberian vitamin $\mathrm{C}$ dipengaruhi oleh umur dan nilai C-ACT sebelumnya. Anak berumur 7-8,2 tahun dengan nilai C-ACT 18-19 didapatkan peningkatan nilai 4,2 (IK95\%: 3,3-5,3), umur 8,3-10 tahun dengan nilai C-ACT sebelumnya 14-15 terdapat peningkatan nilai 1,3 (IK95\%: 0,12,5). ${ }^{15}$ Al-Blitagi dkk ${ }^{14}$ menilai C-ACT anak umur 7-10 tahun dengan diet harian secara normal, tetapi berbeda pada subjek pasien asma persisten sedang yang menunjukkan peningkatan nilai C-ACT setelah pemberian vitamin $\mathrm{C}(\mathrm{p}<0,001)$.

Pemberian vitamin $\mathrm{C}$ dapat mengontrol serangan asma. Hal tersebut berdasarkan tidak terdapatnya perubahan nilai C-ACT maupun kadar $\mathrm{LTE}_{4}$ urin dan juga penurunan jumlah anak yang mengalami serangan asma. Uji Spearman menunjukkan korelasi negatif yang bermakna, tetapi dengan kekuatan korelasi yang sangat lemah antara kadar $\mathrm{LTE}_{4}$ urin dan nilai C-ACT sebelum dan setelah pemberian vitamin C. Hasil tersebut dapat menunjukkan bahwa dengan penurunan kadar $\mathrm{LTE}_{4}$ urin akan terjadi peningkatan nilai C-ACT dan sebaliknya, apabila jumlah subjek diperbesar.

Penelitian ini memiliki kelebihan yaitu melakukan pemeriksaan non invasif pada anak sehingga orang tua/wali bersedia mengikutsertakan anaknya. Namun, penelitian ini juga memiliki kelemahan, yaitu penggunaan pasien asma anak episodik jarang yang terkontrol baik dengan kadar $\mathrm{LTE}_{4}$ urin yang relatif stabil.

\section{Kesimpulan}

Hasil penelitian ini menyimpulkan pemberian vitamin $\mathrm{C}$ pada pasien asma anak dapat memperbaiki klinis asma, meskipun kadar $\mathrm{LTE}_{4}$ urin dan nilai C-ACT tidak mempunyai korelasi sebelum dan setelah pemberian vitamin $\mathrm{C}$.

\section{Daftar pustaka}

1. Mark JD. Pediatric Asthma: an integrative approach to care. Nutr Clinl Pract 2009;24:578-88.

2. Braman SS. The global burden of asthma. Chest 2006; 130:4-12S.

3. Judarwanto B. Asthma prevalence and statistic 19802010. Diakses tanggal 6 Mei 2012. Diunduh dari http:// childrenallergyclinic.wordpress.com/2010/11/09/asthmaprevalence-and statistic-2010/.

4. Kartasasmita CB. Epidemiologi asma anak. Dalam: Rahajoe NN, Supriyatno B, Setyanto DB, penyunting. Buku ajar respirologi anak. Ed I. Jakarta: Badan Penerbit IDAI;2008.h.71-84.

5. Thomasa M, Kay S, Pike J, William A, Rosenzweigc JRC, Price D. The asthma control testTM (ACT) as a predictor of GINA guideline-defined asthma control: analysis of a multinational cross-sectional survey. Prim Care Respir J 2009;18:41-9.

6. Mapi Research Institute. Childhood asthma control test for children 4 to 11 years old. South Africa/English : Mapi Research Institute, 2006. 
7. Madiono B. Perkiraan besar sampel. Dalam: Sastroasmoro S, Ismael S, penyunting. Dasar-dasar metodologi penelitian. Edisi ke-4. Jakarta: Sagung Seto; 2011.h.34882.

8. Mathur SK, Busse WW. The biology of asthma. Dalam: Fishman AP, Elias JA, Fishman JA,Grippi MA,Senior RM, Pack AP, penyunting. Fishman's pulmonary diseases and disorders. Vol 1. Edisi ke-4. New York: McGrawHill; 2008.h.773-86.

9. Wenzel SE. The role of leukotrienes in asthma. Prostaglandins Leukot Essent Fatty Acids 2003;69:14555.

10. Austen KF, Maekawa A, Kanaoka Y, Boyce JA. The leukotriene $\mathrm{E}_{4}$ puzzle: finding the missing pieces and revealing the pathobiologic implications. J Allergy Clin Immunol 2009;124:406-14.

11. Tumbelaka AR, Riono P, Sastroasmoro S, Wirjodiarjo M, Pudjiastuti P, Firman K. Pemilihan uji hipotesis. Dalam:
Sastroasmoro S, Ismael S. Dasar-dasar metodologi penelitian. Edisi ke-4. Jakarta: Sagung Seto; 2011.h.32446.

12. Roy P, Kulkarni P. Oxidation of ascorbic acid by lipoxygenase: effect of selected chemicals. Food Chem Toxicol 1996;34:563-70.

13. Severien C, Artlich A, Jonas A, Beche G. Urinary excretion of leukotrien $\mathrm{E}_{4}$ and eosinophil protein $\mathrm{x}$ in children with atopic asthma. Eur Respir J 2000;16:58892.

14. Al-Blitagi M, Basel AA, Bassiouny M, Al Kasrawi M, Attia M. Omega-3 fatty acids, vitamin $\mathrm{C}$ and $\mathrm{Zn}$ supplementation in asthmatic children: a randomized self-controled study. Acta Paediatr 2009;98:737-42.

15. Hemilä H, Al-Biltagi M, Baset AA. Vitamin C and asthma in children : modification of the effect by age, exposure to dampness and severity of asthma. Clin and Translational Allergy 2011;1:2-9. 